\title{
Financial Performance Analysis of Sharia Banks in Indonesia and Malaysia Using Dupont System
}

\author{
Moena Azizah*, Nengzih
}

Mercu Buana University Jakarta

\author{
DOI: $\underline{10.36348 / \text { sjef.2021.v05i01.003 }}$ \\ *Corresponding author: Moena Azizah
}

| Received: 10.01.2021 | Accepted: 21.01.2021 | Published: 22.01.2021

\section{Abstract}

The purpose of this research is to analyze and determine the financial performance of Islamic banking in Indonesia and Islamic banking in Malaysia using the Dupont System, represented by the ratio of NPM (Net Profit Margin), TATO (Total Asset Turnover), ROI (Return On Investment), MER (Multyplyer Equity). Ratio) and ROE (Return On Equity). This research uses quantitative data, using secondary data sources by using library studies and library research using different test $\mathrm{T}$ in each ratio. Based on the results of the study, it shows that there are significant differences in the ratio of NPM, TATO, ROI and ROE. In contrast, for the MER ratio, there is no significant difference between Islamic banking in Indonesia and Malaysia.

Keywords: NPM, TATO, ROI, MER, ROE

Copyright ( $\odot 2021$ The Author(s): This is an open-access article distributed under the terms of the Creative Commons Attribution 4.0 International License (CC BY-NC 4.0) which permits unrestricted use, distribution, and reproduction in any medium for non-commercial use provided the original author and source are credited.

\section{INTRODUCTION}

Asia plays an essential role in the global economy and the Islamic financial system. This is evidenced by total Islamic finance assets which recorded an annual growth of $13.1 \%$ between 2010 and 2016. Asia has been a pioneer in several Islamic financial institutions. Now Islamic financial institutions in Asia are increasingly innovative in creating economic growth that has an impact on economic advancement in Asian countries [1-5].

Malaysia, Bangladesh, Brunei, and Indonesia are some examples of countries that are concerned about developing Islamic banking in Asia. The total assets of Malaysian Islamic banking since its establishment amounted to 182.8 billion USD, which was $67.5 \%$ of the assets of Islamic banking in the Asian region in 2017-followed by Bangladesh with 30.3 billion USD or $11.2 \%$ and Indonesia with 26.9 billion USD or $9.9 \%$ [6-9].

Observing asset growth alone is not enough to provide an overview of the development of sharia. Other essential aspects must also be considered and explored including NPM ( Net Proft Margin) to measure companies in generating net income, asset turnover as measured by TATO (Total Asset Turn Over), ROI (Return on Investment) measures the return on investment, MER (Multiplier Equity Ratio) compares assets and equity and ROE (Return on Equity) capital in the company [10-15].

Performance evaluation is a method of measuring the achievement of a company based on predetermined targets. This is part of a control measure that can help the company improve its future performance by identifying deficiencies in its operations throughout the financial year. Having the right performance measurement system is essential, especially in today's borderless world, to remain financially competitive and robust [16-18].

Assessing the performance of Islamic banking is one way to determine the soundness of a bank because by looking at the performance it will be seen how the bank can carry out its function correctly as an intermediary institution, a trusted institution for the public to save money, and how Islamic banks can carry out their social functions (CSR). The measurement of financial performance is crucial in its role concerning this problem $[19,20]$.

In this study, to measure the financial performance of Islamic banking in Indonesia and Malaysia, the Dupont method is used [21].

\section{LITERATURE REVIEW Signalling Theory}

Signal theory is one way to understand financial management in companies, especially Islamic 
banking companies. This signal can be in the form of information on what direction has done in processing funds from investors.

From this information, investors can find out how changes in the financial performance of banks that occur each period so that it can influence the value of the banking sector itself. There is a positive correlation between the number of shares or the number of incoming funds and the company's financial statements. If there is "good news" presented, there will be many investors who invest in the company, and the opposite will apply.

\section{Financial Statements}

Financial reports are the result of an accounting process that is commonly used as a means of communication with interested parties based on financial conditions and the consequences of financial operations. The condition of the company can be seen from the company's financial statements. Likewise, with banking, banking financial reports aim to provide information relating to financial position, performance and changes in financial situation. Banking financial reports are also useful for decision making for external and internal parties.

\section{Financial Performance}

Financial performance is a reflection of the achievement of a company's success. It can be interpreted as the results that have been achieved for various activities that have been carried out. The company's financial performance is one of the bases for assessing the company's financial condition, which can be done based on an analysis of the company's financial ratios. Excellent or lousy banking financial performance and the success or failure of achieving business performance can be measured by a financial benchmark called the financial ratio. Measurement of banking performance can be carried out.

\section{Dupont System}

The Dupont analysis method is often used in particular for division control; the process is called controlling the rate of return on investment (ROI). If the ROI for a particular division is below the target number, through the Dupont Method, the causes of the decrease in ROI can be traced. If the ROI is multiplied by the Equity Multiplier, it will produce ROE (Return On Equity). ROI (profit resulting from overall investment in assets) is a product of net profit margin (profit generated from sales) and total asset turnover (the company's ability to generate sales from its assets).

\section{Hypothesis}

H1: There is a significant difference in the value of Net Profit Margin (NPM) in Indonesia and Malaysia

$\mathrm{H} 2$ : There is a significant difference in the value of Total Asset Turnover (TATO) in Indonesia and Malaysia

H3: There is a significant difference in the value of Return On Investment (ROI) in Indonesia and Malaysia $\mathrm{H}_{4}$ : There is a significant difference in the value of Multiplier Equity Ratio (MER) in Indonesia and Malaysia

H5: There is a significant difference in the value of Return On Equity (ROE) in Indonesia and Malaysia

\section{METHODOLOGY}

This type of research data is secondary data research. The number of samples in this study was 105 . The sampling technique in this study, namely by using a purposive sampling method. The test tool used in SPSS 25.

\section{Data Analysis}

\section{Net Profit Margin}

It is a measure of the percentage of each remaining sales after deducting all costs and expenses Profit After Tax X 100\% Income

\section{Total Asset Turnover}

That has a utility to measure the velocity of turnover of assets used by the company in a certain period

\section{Income}

Assets

\section{Return On Investment}

Namely, to see the rate of return received on investment issued.

\section{NPM $x$ TATO}

\section{Multiplier Equity Ratio}

Namely, a financial ratio to calculate how much equity or capital is compared to the company's total assets or how much assets are financed by debt.

$$
\frac{\text { Assets }}{\text { Equity }}
$$

\section{Return On Equity}

It is a ratio to measure the rate of return of the company or banking on all existing capital.

\section{ROI $x$ MER}




\section{RESULTS AND DISCUSSION}

Results of Calculation of the Dupont System for Indonesian Islamic Banking 2014-2018

\begin{tabular}{|l|l|l|l|l|l|}
\hline & NPM & TATO & ROI & MER & ROE \\
\hline BCAS & $8,43 \%$ & 0,08 & $0,67 \%$ & 4,86 & $3,30 \%$ \\
\hline BJBS & $-20,15 \%$ & 0,10 & $-1,96 \%$ & 8,31 & $-17,50 \%$ \\
\hline BMI & $1,38 \%$ & 0,07 & $0,10 \%$ & $\mathbf{1 4 , 6 8}$ & $1,50 \%$ \\
\hline BMS & $7,71 \%$ & $\mathbf{0 , 1 2}$ & $0,78 \%$ & 6,62 & $4,75 \%$ \\
\hline BNIS & $\mathbf{9 , 7 1 \%}$ & 0,10 & $\mathbf{0 , 9 4 \%}$ & 10,12 & $\mathbf{9 , 5 4 \%}$ \\
\hline BRIS & $3,73 \%$ & 0,09 & $0,35 \%$ & 10,58 & $3,64 \%$ \\
\hline BSB & $-0,04 \%$ & 0,09 & $-0,01 \%$ & 9,03 & $-0,20 \%$ \\
\hline BSM & $4,39 \%$ & 0,08 & $0,36 \%$ & 12,72 & $4,36 \%$ \\
\hline BVS & $-7,84 \%$ & 0,09 & $-0,75 \%$ & 7,71 & $-6,28 \%$ \\
\hline MSI & $-80,69 \%$ & 0,08 & $-7,46 \%$ & 2,08 & $-15,09 \%$ \\
\hline PSB & $-18,96 \%$ & 0,08 & $-1,77 \%$ & 11,25 & $-67,84 \%$ \\
\hline
\end{tabular}

From the above data, it can be seen that in Islamic banking in Indonesia, the highest NPM ratio at BNIS (Bank Negara Indonesia Syariah) 9.71\%. The highest TATO ratio is found in BMS (Bank Mega Syariah) of 0.12 times. The highest ROI ratio at BNIS is $0.94 \%$. The highest MER ratio for BMI (Bank
Muamalat) is 14.68. The highest ROE ratio at BNIS was $9.54 \%[22,23]$.

Results of Calculation of the Dupont System for Malaysian Islamic Banking 2014-2018

\begin{tabular}{|l|l|l|l|l|l|}
\hline & NPM & TATO & ROI & MER & ROE \\
\hline AFIBB & $12,90 \%$ & 0,04 & $0,51 \%$ & 13,91 & $7,01 \%$ \\
\hline ALIBB & $40,09 \%$ & 0,03 & $1,08 \%$ & 10,56 & $11,44 \%$ \\
\hline AMIB & $\mathbf{9 4 , 1 1 \%}$ & $\mathbf{0 , 0 9}$ & $\mathbf{8 , 1 3 \%}$ & 1,20 & $9,67 \%$ \\
\hline BIMB & $19,65 \%$ & 0,05 & $1,00 \%$ & 13,71 & $\mathbf{1 3 , 8 4 \%}$ \\
\hline BMMB & $12,38 \%$ & 0,05 & $0,62 \%$ & 11,29 & $6,93 \%$ \\
\hline CIMBIB & $18,01 \%$ & 0,04 & $0,79 \%$ & 16,41 & $12,98 \%$ \\
\hline HONGIB & $15,71 \%$ & 0,04 & $0,66 \%$ & 11,72 & $7,76 \%$ \\
\hline MAYIB & $43,12 \%$ & 0,03 & $1,36 \%$ & 8,64 & $11,70 \%$ \\
\hline PURIBB & $18,58 \%$ & 0,04 & $0,79 \%$ & 14,19 & $11,27 \%$ \\
\hline RHBIB & $15,00 \%$ & 0,04 & $0,64 \%$ & $\mathbf{1 6 , 6 3}$ & $10,62 \%$ \\
\hline
\end{tabular}

From the data above, it can be seen that in Islamic banking in Malaysia, the highest NPM ratio is AMIB (AmBank Islamic Berhad) of $94.11 \%$. The highest TATO ratio is found in AMIB of 0.09 times. The highest ROI ratio at AMIB is $8.13 \%$. The highest MER ratio on RHBIB (RHB Islamic Bank Berhad) is
16.63. The highest ROE ratio at BIMB (Bank Islam Malaysia Berhad) was $13.84 \%$ [24].

\section{Hypothesis Testing NPM \\ Descriptive Analysis}

\begin{tabular}{|l|l|l|l|l|l|l|l|}
\hline \multicolumn{1}{|l|}{ Descriptive Statistics } & $\mathrm{N}$ & Range & Min & Max & Sum & Mean & Std. Dev. \\
\hline & 11 & 0,904 & $-0,807$ & 0,097 & $-0,924$ & $-0,084$ & 0,261 \\
\hline NPM Indonesia & 10 & 0,817 & 0,124 & 0,941 & 2,895 & 0,290 & 0,254 \\
\hline NPM Malaysia & 10 & & & & & & \\
\hline Valid N (listwise) & 10 & & & & & & \\
\hline
\end{tabular}

The number of research objects is 11 Indonesian Islamic banks and 10 Islamic banks in Malaysia, and it can be seen that the mean NPM in
Islamic banks in Malaysia is higher at 0.290, while in Indonesia it is -0.084 , the difference between the two indexes is 0.3735 or $37.35 \%$ [25]. 


\section{Normality Test}

\begin{tabular}{|c|c|c|c|}
\hline \multicolumn{4}{|c|}{ One-Sample Kolmogorov-Smirnov Test } \\
\hline & & & NPM \\
\hline \multicolumn{3}{|l|}{$\mathrm{N}$} & 21 \\
\hline \multicolumn{3}{|l|}{ Test Statistic } & 0,23 \\
\hline \multicolumn{3}{|l|}{ Asymp. Sig. (2-tailed) } & $.005^{\mathrm{c}}$ \\
\hline \multirow[t]{3}{*}{ Monte Carlo Sig. (2-tailed) } & \multicolumn{2}{|l|}{ Sig. } & $.185^{\mathrm{d}}$ \\
\hline & \multirow[t]{2}{*}{$99 \%$ Confidence Interval } & Lower Bound & 0,175 \\
\hline & & Upper Bound & 0,195 \\
\hline
\end{tabular}

Based on the data on the results of the normality test for the NPM ratio in Islamic banks in Indonesia and Malaysia for the 2014-2018 period, the value is statistical test 0.230 with a significant probability of 0.185 and the value is above 0.05 or $\alpha>$
0.05. This means that the null hypothesis is not rejected or the NPM variable is normally distributed [26].

\section{Hypothesis 1 Testing}

\begin{tabular}{|l|l|l|l|l|l|l|}
\hline \multicolumn{2}{|l|}{ Independent Samples Test } \\
\hline \multicolumn{2}{|c|}{} & \multicolumn{2}{l|}{$\begin{array}{l}\text { Levene's Test for Equality } \\
\text { of Variances }\end{array}$} & \multicolumn{3}{l|}{ t-test for Equality of Means } \\
\cline { 3 - 8 } & F & Sig. & T & Df & Sig. (2-tailed) \\
\hline \multirow{2}{*}{ NPM } & Equal variances assumed & 0,013 & 0,911 & $-3,3$ & 19 & 0,004 \\
\cline { 2 - 8 } & Equal variances not assumed & & & $-3,3$ & 18,9 & 0,004 \\
\hline
\end{tabular}

The $\mathrm{t}$ value for NPM is -3.32 with a significance value of 0.004 . Because the significance value is $0.004<0.05$ on this basis, it can be concluded that $\mathrm{H} 0$ is rejected or there is a significant difference in the ratio of NPM.

\section{Hypothesis Testing TATO \\ Descriptive Analysis}

\begin{tabular}{|l|l|l|l|l|l|l|l|}
\hline Descriptive Statistics & N & Range & Min & Max & Sum & Mean & Std. Deviation \\
\hline & 11 & 0,048 & 0,071 & 0,119 & 0,994 & 0,090 & 0,013 \\
\hline TATO Indonesia & 10 & 0,060 & 0,027 & 0,087 & 0,459 & 0,046 & 0,016 \\
\hline TATO Malaysia & 10 & & & & & & \\
\hline Valid N (listwise) & 10 & & & & & & \\
\hline
\end{tabular}

The average (mean) TATO Islamic bank in Malaysia is higher, amounting to 0.090, while Indonesia amounted to 0,046 difference from the second index is 0.0444 or $4.44 \%$ [27].

\section{Normality Test}

\begin{tabular}{|c|c|c|c|}
\hline \multicolumn{4}{|c|}{ One-Sample Kolmogorov-Smirnov Test } \\
\hline & & & TATO \\
\hline \multicolumn{3}{|l|}{$\mathrm{N}$} & 21 \\
\hline \multicolumn{3}{|l|}{ Test Statistic } & 0,18 \\
\hline \multicolumn{3}{|l|}{ Asymp. Sig. (2-tailed) } & $.074^{\mathrm{c}}$ \\
\hline \multirow[t]{3}{*}{ Monte Carlo Sig. (2-tailed) } & \multicolumn{2}{|l|}{ Sig. } & $.456^{\mathrm{d}}$ \\
\hline & \multirow[t]{2}{*}{ 99\% Confidence Interval } & Lower Bound & 0,443 \\
\hline & & Upper Bound & 0,469 \\
\hline
\end{tabular}

The results of the TATO ratio normality test showed a statistical value test of 0.18 with a significant probability of 0.456 and a value above 0.05 or value of $\alpha>0.05$. This means that the $\mathrm{H} 0$ is not rejected or the TATO variable is normally distributed. 


\section{Hypothesis 2 Testing}

\begin{tabular}{|l|l|l|l|l|l|l|}
\hline \multicolumn{2}{|l|}{ Independent Samples Test } \\
\hline \multicolumn{2}{|c|}{} & Levene's Test for Equality of Variances & \multicolumn{3}{|c|}{ t-test for Equality of Means } \\
\cline { 3 - 7 } \multicolumn{2}{|c|}{ TATO } & F & Sig. & t & Df & Sig. (2-tailed) \\
\cline { 2 - 7 } & Equal variances assumed & 0,008 & 0,931 & 7,01 & 19 & 0,000 \\
\hline
\end{tabular}

The $\mathrm{t}$ value for the TATO ratio is 7,007 with a significance value of 0,000 . Due to the significant value of $0.000<0.05$ based on this we can conclude that $\mathrm{H} 0$ is rejected or there is a significant difference in TATO ratio [28].

\section{Hypothesis Testing ROI \\ Descriptive Analysis}

\begin{tabular}{|l|l|l|l|l|l|l|l|}
\hline Descriptive Statistics & R & Range & Min & Max & Sum & Mean & Std. Dev. \\
\hline ROI Indonesia & 11 & 0,084 & $-0,075$ & 0,009 & $-0,089$ & $-0,00809$ & 0,024 \\
\hline ROI Malaysia & 10 & 0,076 & 0,005 & 0,081 & 0,156 & 0,0156 & 0,023 \\
\hline Valid N (listwise) & 10 & & & & & & \\
\hline
\end{tabular}

Average (mean) ROI in Islamic banks in Malaysia is higher, amounting to 0.0156 while
Indonesia amounting to -0.008 difference of the two indexes amounted to 0.0245 or $2.45 \%$.

\section{Normality Test}

\begin{tabular}{|c|c|c|c|}
\hline \multicolumn{4}{|c|}{ One-Sample Kolmogorov-Smirnov Test } \\
\hline & & & ROI \\
\hline \multicolumn{3}{|l|}{$\mathrm{N}$} & 21 \\
\hline \multicolumn{3}{|l|}{ Test Statistic } & 0,274 \\
\hline \multicolumn{3}{|l|}{ Asymp. Sig. (2-tailed) } & $.001^{\mathrm{c}}$ \\
\hline \multirow[t]{3}{*}{ Monte Carlo Sig. (2-tailed) } & \multicolumn{2}{|l|}{ Sig. } & $.125^{\mathrm{d}}$ \\
\hline & \multirow[t]{2}{*}{$99 \%$ Confidence Interval } & Lower Bound & 0,116 \\
\hline & & Upper Bound & 0,134 \\
\hline
\end{tabular}

The results of the ROI ratio normality test showed a statistical value test of 0.274 with a significant probability of 0.125 and a value above 0.05 or value of $\alpha>0.05$. This means that the $\mathrm{H} 0$ is not rejected or the ROI variable is normally distribute [29].

\section{Hypothesis 3 Testing}

\begin{tabular}{|c|c|c|c|c|c|c|}
\hline \multicolumn{7}{|c|}{ Independent Samples Test } \\
\hline & & \multicolumn{2}{|c|}{ Levene's Test for Equality of Variances } & \multicolumn{3}{|c|}{ t-test for Equality of Means } \\
\hline & & $\mathrm{F}$ & Sig. & $\mathrm{T}$ & Df & Sig. (2-tailed) \\
\hline \multirow[t]{2}{*}{ ROI } & Equal variances assumed & 0,151 & 0,702 & $-2,3$ & 19 & 0,034 \\
\hline & Equal variances not assumed & & & $-2,3$ & 19 & 0,034 \\
\hline
\end{tabular}

The $\mathrm{t}$ value for $\mathrm{ROI}$ is -2.28 with a significance value of 0.034 . Because the significance value of 0.034 $<0.05$ on this basis, it can be concluded that $\mathrm{HO}$ is

rejected or there is a significant difference in the ROI ratio.

\section{Hypothesis Testing MER Descriptive Analysis}

\begin{tabular}{|l|l|l|l|l|l|l|l|}
\hline Descriptive Statistics & Range & Min & Max & Sum & Mean & Std. Dev. \\
\hline MER Indonesia & 11 & 12,603 & 2,075 & 14,678 & 97,959 & 8,90536 & 3,57356 \\
\hline MER Malaysia & 10 & 15,434 & 1,197 & 16,631 & 118,256 & 11,8256 & 4,50456 \\
\hline Valid N (listwise) & 10 & & & & & & \\
\hline
\end{tabular}


It is known that the average (mean) MER in Islamic banks in Malaysia is higher, which is 11,826 , while in Indonesia, it is 8.9054 , the difference between the two indices is 2.9203 .

\section{Normality Test}

\begin{tabular}{|c|c|c|c|}
\hline \multicolumn{4}{|c|}{ One-Sample Kolmogorov-Smirnov Test } \\
\hline & & & MER \\
\hline \multicolumn{3}{|l|}{$\mathrm{N}$} & 21 \\
\hline \multicolumn{3}{|l|}{ Test Statistic } & 0,102 \\
\hline \multicolumn{3}{|l|}{ Asymp. Sig. (2-tailed) } & $.200^{\mathrm{c}, \mathrm{d}}$ \\
\hline \multirow[t]{3}{*}{ Monte Carlo Sig. (2-tailed) } & \multicolumn{2}{|l|}{ Sig. } & $.965^{\mathrm{e}}$ \\
\hline & \multirow[t]{2}{*}{$99 \%$ Confidence Interval } & Lower Bound & 0,96 \\
\hline & & Upper Bound & 0,969 \\
\hline
\end{tabular}

Based on the normality test data, the MER ratio shows a statistical value test of 0.102 with a significant probability of 0.965 and a value above 0.05 or value of $\alpha>0.05$. This means that the H0 is not rejected or the MER variable is normally distributed [30].

\section{Hypothesis 4 Testing}

\begin{tabular}{|l|l|l|l|l|l|l|}
\hline \multicolumn{2}{|l|}{ Independent Samples Test } & \multicolumn{4}{l|}{ Levene's Test for Equality of Variances } & \multicolumn{2}{l|}{$\begin{array}{l}\text { t-test for Equality of } \\
\text { Means }\end{array}$} \\
\cline { 3 - 8 } & & F & Sig. & T & Df & Sig. (2-tailed) \\
\hline \multirow{2}{*}{ MER } & Equal variances assumed & 0,139 & 0,713 & $-1,7$ & 19 & 0,115 \\
\cline { 2 - 7 } & Equal variances not assumed & & & $-1,6$ & 17,2 & 0,12 \\
\hline
\end{tabular}

The $\mathrm{t}$ value for MER is -1.65 with a significance value of 0.115 . Because the significance value $0.115>0.05$ on this basis, it can be concluded that

\section{Hypothesis Testing ROE Descriptive Analysis}

\begin{tabular}{|l|l|l|l|l|l|l|l|}
\hline \multicolumn{1}{|l|}{ Descriptive Statistics } & N & Range & Min & Max & Sum & Mean & Std. Dev. \\
\hline ROE Indonesia & 11 & 0,773 & $-0,678$ & 0,095 & $-0,798$ & $-0,0725$ & 0,21796 \\
\hline ROE Malaysia & 10 & 0,069 & 0,069 & 0,138 & 1,032 & 0,1032 & 0,02423 \\
\hline Valid N (listwise) & 10 & & & & & & \\
\hline
\end{tabular}

It can be seen that the average (mean) ROE of Islamic banks in Malaysia is higher, namely, 1.0320, while in Indonesia, it is -0.0798 , the difference between the two indices is 1.11 .
$\mathrm{HO}$ is accepted or there is no significant difference in the MER ratio.

\begin{abstract}
Normality Test
ROE ratio normality test data shows a statistical value test of 0.28 with a significant probability of 0.059 and a value above 0.05 or value of $\alpha>0.05$. This means that the $\mathrm{H} 0$ is accepted or the ROE variable is normally distributed.
\end{abstract}

\begin{tabular}{|c|c|c|c|}
\hline \multicolumn{4}{|c|}{ One-Sample Kolmogorov-Smirnov Test } \\
\hline & & & ROE \\
\hline \multicolumn{3}{|l|}{$\mathrm{N}$} & 21 \\
\hline \multicolumn{3}{|l|}{ Test Statistic } & 0,28 \\
\hline \multicolumn{3}{|l|}{ Asymp. Sig. (2-tailed) } & $.000^{\mathrm{c}}$ \\
\hline \multirow[t]{3}{*}{ Monte Carlo Sig. (2-tailed) } & \multicolumn{2}{|l|}{ Sig. } & $.059^{\mathrm{d}}$ \\
\hline & \multirow[t]{2}{*}{$99 \%$ Confidence Interval } & Lower Bound & 0,053 \\
\hline & & Upper Bound & 0,065 \\
\hline
\end{tabular}




\section{Hypothesis 5 Testing}

\begin{tabular}{|c|c|c|c|c|c|c|}
\hline \multicolumn{7}{|c|}{ Independent Samples Test } \\
\hline & & \multicolumn{2}{|c|}{ Levene's Test for Equality of Variances } & \multicolumn{3}{|c|}{ t-test for Equality of Means } \\
\hline & & $\mathrm{F}$ & Sig. & $\mathrm{T}$ & Df & Sig. (2-tailed) \\
\hline \multirow[t]{2}{*}{$\mathrm{ROE}$} & Equal variances assumed & 6,006 & 0,024 & $-2,5$ & 19 & 0,02 \\
\hline & Equal variances not assumed & & & $-2,7$ & 10,3 & 0,024 \\
\hline
\end{tabular}

The $t$ value of $\mathrm{ROE}$ ratio is -2.53 with a significance value of 0.024 . Because the significance value of $0.024<0.05$ on this basis, it can be concluded that $\mathrm{HO}$ is rejected or there is a significant difference in the ROE ratio.

\section{CONCLUSION}

1. Ratio Net Profit Margin (NPM) there is a significant difference in the financial performance of Islamic banking in Indonesia and Malaysia for the 2014-2018 period.

2. Ratio Total Asset Turnover (TATO) there is a significant difference in the financial performance of Islamic banking in Indonesia and Malaysia for the 2014-2018 period.

3. The ratio of Return On Investments (ROI) there is a significant difference in the financial performance of Islamic banking in Indonesia and Malaysia for the 2014-2018 period.

4. Ratio MultyplierEquity Ratio (MER) there is no significant difference in the financial performance of Islamic banking in Indonesia and Malaysia the period 2014-2018.

5. The ratio Return on Equity (ROE) is a significant difference in the financial performance of Islamic banking in Indonesia and Malaysia for the 20142018 period

\section{SUGGESTION}

1. For investors and potential investors in Islamic banks, you should pay attention to the financial banking ratios, predominantly the ROI and ROE ratios.

2. For Islamic banking, especially in Indonesia, to take advantage of Islamic banking in Malaysia. Indonesia is one of the countries with the largest Muslim population in the world; this is a driving factor for the development of Islamic entities, especially banking.

3. For further researchers, it is hoped that it can increase the number of countries that will be used as the research sample and the more extended research year.

\section{REFERENCES}

1. Ahmad, A. M. (2018). Financial Performance Analysis of Islamic Bank and Conventional Bank in Pakistan 2015-2017 A Comparative Study. Journal international, Department of Islamic Studies Gift University Gujrawala.
2. Alqahtani, F., David, G., Mayes, B., \& Kym, B. (2016). Reprint of Economic turmoil and Islamic banking: Evidence from the Gulf Cooperation Council. Pacific-Basin Finance Journal PACFIN00866; 13.

3. Aref, A. A. (2013). A Comparison of Financial Performance between Samba and AlRajhi Banks by Using Dupont Model. Journal of Finance and Investment Analysis, 2(4), 83-95.

4. Aurora, T., Lubis, Z., \& Noria, S. (2015). Analisis Kinerja Keuangan Perusahaan dengan Metode Dupont Sistem pada Industri Food and Bverages yang Terdaftar di Bursa Efek Indonesia Periode (2012-2014). Jurnal Ekonomi dan Bisnis Fakultas Ekonomi dan Bisnis Universitas Jambi.

5. Botika, M. (2012). The use of Dupont analysis in abnormal returns evaluation: Empirical study of Romanian market. Financial Analyst atHewlettPackard Company\&PhD student in Finance at The Bucharest Academy of Economic Studies.

6. Burja, V., \& Radu, M. (2014). The study of factors that may influence the performance by the Dupont analysis in the furniture industry. Procedia Economics and Finance, 16; 213-223.

7. Ghozali, I. (2011). Aplikasi Analisis Multivariate dengan Program IBM SPSS 19. Semarang: Badan Penerbit Universitas Diponegoro.

8. Hazzi, O. A., \& Kilani, M. I. A. (2013). The financial performance analysis of Islamic and traditional banks: Evidence from Malaysia. European Journal of Economics, Finance and Administrative Sciences, 57, 133144.

9. Herliansyah, Y., Nugroho, L., Ardilla, D., \& Putra, Y. M. (2020). The Determinants of Micro, Small and Medium Enterpreneur (MSME) Become Customer of Islamic Banks (Religion, Religiousity and Location of Islamic Banks). In The 1st Annual Conference Economics, Business, and Social Sciences (Vol. 2).

10. Islamic Financial Services Board. (2019). Islamic financial services Industry Stability report 2019. Emerging Issues in Islamic Finance.

11. Jumingan. (2012). Analisis Laporan Keuangan. Surakarta. Bumi Aksara.

12. Kasmir. (2012). Analisis Laporan Keuangan. Jakarta. RajaGrafindo Persada.

13. Mongi, L. (2018). Comparative study on Credit Risk in Islamic Banking Institutions: The Case of Malaysia. Quarterly Review of Economics and Finance 
14. Munawir. (2001). Analisa Laporan Keuangan. Edisi Keempat. Yogyakarta: Liberti.

15. Nur, A., Nurul, S., Ahmad Syubali dan Mohd Naim. (2018). Determinants of Financial Performance of Islamic Banking in Malaysia. International Journal of Academic Research in Accounting, Finance and Management Sciences, 8(4), 21-29.

16. Nengzih. (2016). Corporate Governance, Environmental Management Accounting and Financial Performance of Indonesia's State-Owned Companies. International Journal of Business, Economics and Law, 9.

17. Novera, W. (2017). Tingkat Kesehatan Perbankan Syariah : Studi Komparatif Indonesia dan Malaysia dengan Pendekatan Metode Camel. Skripsi. Fakultas Ekonomi dan Bisinis. UIN Syarifhidayatullah.

18. OJK, Sejarah Perbankan Syariah di Indonesia, (2017).

https://www.ojk.go.id/id/kanal/syariah/tentangsyariah/Pages/Sejarah-Perbankan-Syariah.aspx

19. Rama, A. (2015). Analisis Deskriptif Perkembangan Bank Syariah di Asia Tenggara, The journal of Tauhidnomics, 1(2):105-123.

20. Rao, A. (2005). Cost frontier efficiency and riskreturn analysis in an emerging market. nternational Review of Financial Analysis, 14; 283-303.

21. Sabir, M. M., Muhammad, A., \& Abd, H. H. (2012). Pengaruh Rasio Kesehatan Bank Terhadap Kinerja Keuangan Bank Umum Syariah dan Konvensional di Indonesia. Jurnal Analisis, 1(1):79-86.

22. Salman, A., \& Huma, N. (2018). Islamic financial system and conventional banking comparison. Arab economic and Business Journak, 113, 155167.
23. Shehzad, M. M. (2008). Performance of Islamic Banking and Conventional Banking in Pakistan: A Comparative Study. Journal International University of Skövde, School of Technology and Society.

24. Sugiarto. (2016). Metodologi Penelitian Bisnis. Jakarta. Penerbit Andi.

25. Suliyanto. (2018). Metode Penelitian Bisnis. Purwokerto. Penerbit Andi.

26. Sunardi, N. (2018). Analisis Dupont Sistem dengan Time Series Approach (TSA) dan Cross Sectional Approach (CSA) dalam Penilaian Kinerja Keuangan Perusahaan (Studi Pada Industri Konstruksi (BUMN) di Indonesia Yang Listing di BEI Tahun 2013-2017). SEKURITAS (Saham, Ekonomi, Keuangan dan Investasi), 1(4), 1-15.

27. Wibowo, S. (2015, Januari-Juni). Analisis Perbandingan Kinerja Keuangan Perbankan Syariah dengan Metode CAMEL di ASEAN (Studi Komparatif: Indonesia, Malaysia dan Thailand). Jurnal Riset Ekonomi dan Manajemen, 15(1),136-153.

28. Widyawati, W. (2018). Analisis Komparatif Tingkat Kesehatan Perbankan dengan Metode CAMELS di ASEAN (Studi pada Bank Umum Indonesia, Malaysia, Singapura,Thailand, dan Filipina Tahun 2012-2016. Jurnal Ilmu Manajemen Volume 6 Nomor 4- Jurusan Manajemen Fakultas Ekonomi Universitas Negeri Surabaya.

29. Yildiril, İ. (2016). Financial Differences and Similarities of Islamic Banks; A Study on QISMUT Countries. Journal of Business, Economics \& Finance ISSN: 2146 - 7943.

30. Yomna, D., \& dan Kammoun, A. (2017). Financial Performance Analysis of Islamic Banks in Tunisia. Asian Economic and Financial Review. 7(8), 780-789. 